\title{
A Study on Cultivating Chinese College Students' Cultural Confidence in College English Teaching
}

\author{
Rongqin Ma \\ International Education College, \\ Xi'an Peihua University \\ Chang'an Campus, Xi'an, China
}

\begin{abstract}
Chinese culture is ignored in College English teaching in Chinese colleges and universities, which leads to the phenomenon of "Chinese culture aphasia" in cross-culture communication between Chinese college students and foreigners. This essay aims to strengthen the cultivation of Chinese college students' cultural confidence from three aspects: knowledge, ability and quality of cultural confidence in college English teaching in Chinese colleges and universities. Permeating Chinese culture in college English teaching is an important section and an effective way not only to cultivate contemporary college students' cultural confidence and increase their national pride, but also to promote Chinese culture's influence in the international society and shape a positive national image in the international stage.
\end{abstract}

Keywords-college English teaching; cultivate; cultural confidence; Chinese college students

\section{INTRODUCTION}

Cultural confidence is the stable psychological traits of assurance of and affirmation in one's cultural value and vitality through the cultural subject's cognition, criticism, reflection, comparison and approval in his study of culture. It is characterized by high appreciation of the vitality of his culture, strong conviction and emotional attachment in cultural value and great recognition and confidence in the contrast and choice between his own culture and foreign cultures. College English Teaching Guide (the latest official version of the Ministry of Education) points out that college English course is a part of the humanistic education in colleges and universities, bearing both instrumental and humanistic characters. [1] In terms of humanity, one of the important tasks of college English course is to offer cross-cultural education. Although China is a core country in The Belt and Road Initiatives strategy, Chinese college students generally can't correctly speak topics about Chinese culture in English in some cross-cultural communication occasions, resulting in "Chinese cultural aphasia" phenomenon [2]. The main reason why this phenomenon is made by students is to ignore the "two-way" theory of cross-cultural communication. Only Western culture education is immersed in the target language teaching, in the meantime mother language culture is failed to be included. With the continuous improvement of the right of cultural discourse in international exchange, college English teaching in Chinese colleges and universities should gradually bear the important task of cultivating students' national cultural

This paper is the periodical achievement of Peihua Specialized project 2017 sponsored by Xi'an Social Science Planning Fund, A Study on Constructing Theoretical Framework for Cultivating English Majors’ Ability of Cultural Confidence with the project number of 17PH06. confidence and spreading national culture.

\section{The Status Quo of "Cultural ConfidenCE" Education IN CHINESE COLLEGE ENGLISH TEACHING}

\section{A. From the levels of English teachers}

At present, Chinese college English teachers have many years of experience in English culture teaching and learning, and many of them even have rather high academic background and overseas study background, consequently they tend to western cultural values as their own cultural values. It is very common that Chinese English teachers intentionally or unintentionally integrate the western cultural knowledge accumulated over the years into the daily teaching. Therefore, students' ultimate target language cultural acquisition and use are affected by their teachers. Secondly, due to some objective reasons such as curriculum syllabus, teaching content and class hour, teachers can only focus on the target language itself and its culture in Class. The common phenomenon that teachers pay much attention to western culture input but ignore native culture input in language teaching leads to that effective communication is hardly made by the lack of target language knowledge and mother language culture in an actual communication. [3]

\section{B. From the levels of students}

On the one hand, the way of thinking and living habits of Chinese college students, to a great extent, are affected and changed by Western culture since the reform and opening up. The recognition of the culture of English-speaking countries is even more than that of their own national culture, which can be seen easily from the students' passion for Christmas and Valentine's Day. On the other hand, due to the low level of students' English proficiency, they can't use appropriate words to express their understanding about native culture that they have grasped in real communication situations, which leads to the low level of cultural output and greatly weakening the communicative effects.

\section{From the levels of teaching materials}

College English textbooks used in Chinese colleges and universities are all emphasized Western cultural thinking in order to achieve the purest language input. However, English expression of Chinese culture is rarely seen in the teaching materials, nor does contrast and comparison between Chinese 
and Western culture, so it's not strange that students can't use English to express their own culture.

The deficiencies of the cultivation of students' cultural confidence in college English teaching are as following. Teachers pay too much attention to spreading western culture and overemphasize on exam-oriented education; communication related to some cultural knowledge between teachers and students is insufficient; comparison between Chinese and western culture is deficient; cultural knowledge in class is not comprehensive and systematic; university authority does not lay enough emphasis on cultivating of students' cultural confidence etc.

From the mentioned above, it is not hard to see that college English teachers attach importance to the input of Western culture and ignore the spread of their own culture; teachers and students only discuss target language-related cultural topics, but rarely discuss topics about contrast and comparison between Chinese and Western culture in class; owing to advocating Western values and limited language proficiency, students are unable to communicate effectively.

\section{How to Cultivate “CUltural CONFIDENCE” IN ENGLiSH TEACHING}

\section{A. Requirements of cultural confidence knowledge}

Knowledge of cultural confidence includes excellent Chinese traditional culture and socialistic culture. The former refers to the essence of Chinese local culture, which occupies an important position in Chinese traditional culture and has positive impact on the history and people's lives, or can be recognized because of its value of research and development, as well as the ideological and cultural connotations with Chinese characteristics. For example Confucianism, Taoism, Buddhism, Chinese literature, Chinese poetry and wine cultures, Chinese ancient architecture and art, Chinese traditional folk customs, Chinese festivals, some special clothing and her long history, etc. In the process of teaching, teachers should be suggested to increase the penetration of Chinese culture and teach some expression and application of it. However, students should be encouraged to read some Chinese classic works about humanities to learn national culture better. A brand-new teaching model of college English with cultural characteristics should be constructed and be used to guide English teaching.

\section{B. Requirements of cultural confidence competency}

The ability of cultural confidence includes the ability to express Chinese culture in English, the ability of discourse strategy, social communication ability, communicative strategy ability, cross - cultural communication ability and critical thinking ability. It's not far enough for students to accumulate and reserve Chinese traditional culture. Students are required to use their abilities of critical thinking to do taking the essence and discarding the dregs, as well as spread Chinese culture with communicative strategy in the process of cross-culture communication. In the teaching, teachers are encouraged to use like "Socrates teaching methods" in the classroom, namely, teaching is carried out through heuristic questions and refuting way, so as to stimulate students to participate in the discussion of Chinese culture and active speculation. Meanwhile, students should be encouraged to do the class presentation and debate about "Conflicts and Comparison between Western and Chinese Cultures”. Language is the carrier of culture, but also a part of culture. Students only have a mastery of the target language and deep understanding of the system of mother tongue culture, and they can achieve the function of "two-way" language communication and get effective communication. [4]

\section{Requirements of Cultural confidence Quality}

Ultimately, the knowledge and the competence of cultural confidence students grasped in class are embodied in comprehensive quality of cultural confidence students possessed in the real communication. The quality of cultural confidence mainly includes: tolerance, sense of social responsibility, optimism, teamwork, and so on, which are used to measure students' cultural literacy, Chinese feelings and international perspective. In the teaching, classroom and network environment should be used to promote the task of Chinese cultural learning, to improve the quality of culture confidence, to enrich the knowledge of traditional Chinese culture and socialist culture, ultimately to improve their crosscultural communication skills for Chinese culture and critical thinking ability for culture. In the teaching, classroom and network environment should be used to promote the task of Chinese cultural learning, to improve the quality of culture confidence, to enrich the knowledge of traditional Chinese culture and socialist culture, ultimately to improve their crosscultural communication skills for Chinese culture and critical thinking ability for culture. Only when students know Chinese history and culture can they acquire the ability to distinguish the world's culture.

In addition, due to the limited class hour, different teaching content and different requirements of courses in colleges and universities, teachers can't complete all the tasks of culture education in the classroom, which requires students to finish the rest tasks of cultivating cultural confidence after class, meanwhile, the second class activities should be conducted actively. In the specific circumstances after class, students can adopt various of ways such as exploration, hypothesis, contrast, debate to complete the teacher's post-class tasks and to independently develop some interesting topics related to cultural difference, to constantly strengthen students' cultural reflection and cultural action, to improve the ability of language input, organization and output, to ask students to accumulate experience of reflection, so as to achieve common development of cultural confidence both individually and collectively. [5]

The main suggestions to cultivate students' cultural confidence are as following, the permeation of Chinese culture should be enhanced in daily teaching; the correct expression and application of Chinese culture should be increased in language teaching; the status of Chinese culture in students' mind should be improved; the frequency of relevant activities should be increased by university authority; the comparison and analysis between western and Chinese culture from different perspectives; Increasing cultural communication between teachers and students and adding the second class can 
be considered as additional ways to strengthen students' cultural confidence after class.

\section{Significance of Cultivating “Cultural Confidence”}

1) In the college English teaching, strengthening the cultivation of students' cultural confidence helps students master the excellent traditional Chinese culture and modern culture, to cultivate students' cross-cultural communication ability and critical thinking ability, and to improve students' all-round development from aspects of political quality, moral quality, humanistic spirit, national strategic awareness and the quality of international vision.

2) In the college English teaching, strengthening the cultivation of students' cultural confidence helps students deal with the conflict of heterogeneous cultures actively and rationally, to master cultural voice, to maintain national cultural security.

3) In the college English teaching, strengthening the cultivation of students' cultural confidence helps students develop the sense of cultural mission and responsibility so that English can be given full play to its resources and strategic advantages as a cross-cultural communication of Chinese culture in the world, to enhance the international influence of Chinese culture and to shape a positive national image. [6]

\section{CONCLUSION}

Cultural confidence is the embodiment of appreciating for and thinking highly of native culture. College English teaching in China not only pays attention to the acquisition of target language and its culture, and even more melting into Chinese traditional culture, in order to enhance students' cultural confidence and national pride. Meanwhile, only when inputting adequate knowledge of Chinese culture and making comparison between western and Chinese cultures in daily teaching, can help students achieve effective cross-culture communication.

\section{REFERENCES}

[1] "College English Teaching Guide" (the latest version Ministry of Education) 2017

[2] Cong Cong. "Chinese culture aphasia": the shortcomings of English teaching in China. Guangming Daily, 2000.

[3] Xu Dan. College English Teaching in The Cultivation of Cultural confidence status and Enlightenment [J]. New campus (early), 2017, (07): 52-53

[4] Chen Jianping. Language \&Society [M]. Higher Education Press.2011.

[5] Wang Chuanli. The Phenomenon of Chinese Culture Aphasia in English Teaching [J]. Teaching \& Management, 2011, (10):107-108

[6] Bao Renguo. Permeation and Cultivation of Students' Cross-culture Awareness in College English Teaching [J]. Hubei Economic University Journal.2011,08(03):187-189 